\title{
REVISITING HRA / HRR PREPOSITION: HOW TO BRING HUMAN RESOURCE ASSET INTO BALANCE SHEET
}

\author{
SAFDAR ALI BUTT \\ Capital University of Science and Technology, Islamabad, Pakistan
}

\begin{abstract}
While most firms acknowledge the importance of their human resource assets, no firm has as yet tried to show it in its balance sheet. This is due to three main problems: firstly, the absence of a generally acceptable measurement of the value of this asset; secondly, the apparent breach of existing accounting standards and thirdly the possible tax implications. This article offers a solution to all these problems.

The author proposes that the financial value of Human Resource Asset should be equal to the excess of NPV of a firm with existing staff over NPV of the same firm computed on the assumption of having an average quality of staff. Once measured, this asset can be brought to books through a formal accounting entry, debiting Human Resource Asset (to be shown in the Balance Sheet as an intangible asset) and crediting Human Resource Reserve (to be shown in the balance sheet as a non-distributable part of equity). The author also proposes periodic adjustment and prescribes accounting treatment for the same.
\end{abstract}

\section{INTRODUCTION}

In 2013, I wrote a paper on "How to Bring Human Resource Asset into Balance Sheet", putting forward a case for doing so and proposing an accounting treatment that would not breach any accounting standards. This paper appeared in a French journal, Pensee, Vol 75, December 2013. Since then I have received a lot of emails from researchers and finance professionals from different parts of the world on various aspects of issues pertinent to the topic. I have also discussed this paper with a number of my $\mathrm{Ph} \mathrm{D}$ students and presented it at seminars and conferences in and outside Pakistan.

A lot of proverbial water has flown under the bridge since the paper's first publication. I have received some very positive feedback from a number of quarters including some practicing chartered accountants. In light of these communications, I have revisited my HRA/ HRR preposition. But first let us take a look at the basic concept.

\section{The Basic Concept}

Management research literature is replete with studies that claim that the most important asset held by most of the successful companies is their human resource. Almost every chairman extols the virtue of his company's human resource in his annual report. But it all appears to be a part of public relations exercise more than a true belief in the value of this asset as it continues to fail to find a place in any company's balance sheet.

Human resource accounting was defined for the first time by Brummet, Flamholtz \& Pyle (1968) as "a tool for increasing managerial effectiveness in the acquisition, development, allocation, maintenance, and utilization of its human resources". This area was further explored by Sackmann, Flamholtz \& Bullen (1989), Flamholtz, Bullen \& Hua (2002), and Flamholtz, Kannan-Narasimhan \& Bullen (2004).

More interestingly, Morrow (1996 \& 1997) investigated the concept of human resource assets in professional football teams in United Kingdom. Investors consider human resource assets while evaluating a football company in additional to structural and relational capital (Wagner, 2007).

In 1991, Robert Grant came up with his Resources Based Theory of Competitive Advantage which clearly pegged a firm's value to "the substance of its resources", human resource being one of the most important ones. However, he fell short of proposing means of bringing this important resource (that could bestow competitive advantage to a firm and thereby increase its value) into formal books of accounts.

Despite considerable awareness on, and universal acceptance of, the value of human resource very few firms, if indeed any, have ever tried to show this important asset in their balance sheet. This is perhaps due to three main problems: 
- Absence of a generally acceptable measure of the value of this asset;

- Likelihood of breaching accounting standards that are almost invariably in favor of showing intangible assets in the balance sheet at "cost to the firm, rather than value to the firm"; and

- The possible tax implications.

I propose to offer solutions to all three of these problems.

\section{Human Resource Asset or Human Resource Capital}

As a person with finance background, I am disinclined to use the term "capital" for what a firm's human resource means or does for its operations. An asset is what a firm uses to carry out its operations; capital is what you invest to acquire an asset. I therefore believe it is more appropriate to classify the capabilities of a company's human resources as an asset. Funds used to acquire, train and retain such valuable staff undoubtedly come out of capital as the funds used to buy other tangible and non-tangible assets. Just as a plant generates cashflows, and a better plant generates better cashflows - human resource helps a company make profits and better human resource leads a company to make higher profits than its competitors.

However, in accounting terms, an asset must come from somewhere - there has to be a provider of funds to buy these assets - an owner (read equity) or a lender (read liabilities). Equity holders have a dual function - they are the providers of capital to the company but their more important qualification is 'their right to the residual assets of the company'. In this sense, the human resource (being generator of cashflows) is an asset and the benefit of this asset's superiority over other companies essentially goes to the equity holders. I therefore believe that human resource should be called an asset with a counterpart in the balance sheet called Human Resource Reserve, shown as a part of the firm's equity.

\section{Defining Human Resource Asset (HRA)}

Human resource asset represents the potential of future profits that a company holds in the form of having superior leaders, managers and employees. Thus the scope of human resource asset has two distinct facets: firstly it refers to the potential of generating future profits, not actual or past efforts of the people whom a company calls its human resource. Flamholtz (1973 and 1999) relates this idea to economic value theory, stating that all employees possess value because they are capable of rendering future service and their individual value can be defined as present value of the future services he/she is expected to provide for the period of time he/she is expected to remain in the organization. And secondly, HRA includes the efforts of all those who work for the company, at whatever level, be them as the directors, managers or employees of the company. The only caveat we may add here is perhaps that they should be associated full time with the company - thereby excluding temporary or casual workers.

Efforts put in by the employees of the company are paid for almost immediately. In accounting terms, the benefit received from paying out an asset (cash) is treated as an expense which is offset against the current revenues to measure profits. In this sense, it would be unrealistic to call all human effort, or the services of all the employees, as an asset. We need a more formal method of measuring the value of human resource asset.

A large number of papers have been published showing the merits of various methods of accounting treatment of expenditure incurred in acquiring, training, developing and retaining high quality manpower. However, these methods are restricted to treatment of "actual expenditure" only. The inadequacy of these methods will be discussed later in this article.

\section{How to measure the value of HRA?}

Recently, GAAP in USA proposed adoption of more innovative methods with traditional cost approach, transpiring to the indication of encouragement of alternative standards. Thus accountants who are too tied to accounting standards in preparation of financial statements are being offered a possibility to incorporate human resource asset in future annual reports. However, the task is not an easy one.

It is easy, and fairly common, to measure the quality of human resource through various performance evaluation procedures. Many multi-national corporations have elaborate talent assessment schemes which help them identify talent at an early stage and nurture it for handling greater responsibilities in the future. However, the objective of such schemes is to strengthen their HR department by ensuring a constant flow of high caliber managers. Their focus is not on placing a monetary value on their human resource talent. It therefore remains difficult to quantify this asset in monetary terms so as to arrive at a value at which it could be legitimately shown in the balance sheet.

A review of literature shows that several attempts have been made in this regard. Some of the common methods of measuring HRA that have been proposed by researchers over the recent past are enumerated below.

a. Any expenditure incurred on staff training and 
development should be treated as an asset in about the same way as expenditure incurred on product research and development is capitalized - and later amortized over a period. This method suffers from a major defect. Accounting standards in most countries permit the companies to write off product $R \& D$ expense each year in order to benefit from tax shield provided by expensing it instead of treating it as an asset. There are of course exceptions (e.g. where R\&D expense is too large to be absorbed by one accounting year's revenue) but the general practice is not to capitalize product research and development expenditure. If companies were given an option to treat expenditure incurred on staff training and development as an asset, they would most certainly not take the offer as it will deprive them of a valuable tax benefit. (Hongren 1972)

b. Human resource asset be clubbed with what is fashionably known as Intellectual Capital. While it is difficult to argue against the idea of human resource being one of the elements of a firm's intellectual capital, it would be unwise to think that human resource alone constitutes a firm's entire intellectual capital. These are two very different areas. Human Resource Assets should preferably be handled separately from the other elements of a firm's intellectual capital. (Sullivan 2000)

c. HRA may be measured in about the same way as goodwill is measured upon acquisition of a subsidiary. The excess of "total expenditure incurred on acquiring, training and retaining good staff" over the value of their efforts put in the current year should be capitalized. While this method has some merit, it also suffers from tax disadvantage. (IAS 38 and IFRS 3)

d. According to Flamholtz (1973 and 1999), human resource can be measured through two costs i.e. acquisition costs which comprise of direct costs of recruitment, selection, hiring and placement, as well as costs of promotion; and learning costs comprising of the direct costs of formal training and orientation and on-the-job training. These costs should be reported in asset accounts with future economic benefits rather than as expenses in a human resource accounting system According to economic value theory, all employees possess value because they are capable of rendering future service. Thus, individual value of an employee can be defined as "present value of the future services the individual is expected to provide for the period of time the individual is expected to remain in the organization". To compute present value of future services of each and every individual employee of the organization, and to keep revising it upon each movement in personnel, can however be both very expensive and very difficult - and the resultant figure may turn out to be imprecise.

None of the above methods have gained currency among companies of any size, mainly for reasons already stated. I now wish to propose a method that I hope will not only be free from defects suffered by afore-stated methods but also represent the true essence of valuing the human resource asset through a reliable means of measuring such a value. My idea takes inspiration from Flamholtz who has talked about the present value of future efforts of individual employees but goes a little further than that; I propose a more practical approach of applying it to the entire firm.

\section{HRA/HRR Preposition}

My proposition is that the true value of a firm's human resource asset lies in its ability to improve the firm's net present value. If we look at the real situation from the stand point of a simple finance manager, other things being equal, the only thing that will lead a company's net present value to be higher than its competitors' is the quality of its human resource. Opportunities to enhance cashflows exist for all the players in the market; but only those companies that have better manpower (and leaders) are actually able to exploit such opportunities. It is this distinction which truly represents the value of a company's human resource asset. Another way of looking at this proposition is that only if a firm's human resource team is capable of improving its NPV vis-à-vis the firm's competitors can it qualify to be considered as an asset; otherwise it simply represents an already written off expense. An asset in a balance sheet represents a benefit to be received in the future. An expense in the Income Statement represents a benefit already consumed by the firm in the respective accounting period. It therefore follows that an HR team that has potential to improve the future cashflows of the company is an asset, deserving to be placed in the balance sheet. An HR team that does not offer such a potential is not an asset but simply an expense entry in the income statement.

It is therefore proposed that in the first instance, if a company truly believes that its human resource is a real asset that is giving it a competitive advantage, it should prepare two present value statements, based on two separate sets of projected cash flows. The first set of cash flow projections should show what the company with its existing human resource is likely to yield over the next, say, ten years. The second set of cash flow projections 
should be based on the assumption that the company has average standard of employees, not capable of benefiting fully from all the opportunities available to the company in the coming ten years.

In my earlier paper, I had proposed that both the sets of cash flow projections should be discounted using the same discounting rate (may be the company's WACC). I now believe that this approach needs some fine tuning. The first set of cashflows (based on actual human resource commanded by the company) should be discounted at company's prevailing WACC, while the second set of cashflows (based on assumption of an average quality of human resource) should be discounted at the average WACC of the relevant industry in which a firm operates. This change in approach has been prompted by an observation that firms with higher quality human resource are able to command a lower WACC than their competitors. In turn, this should serve to improve the firm's NPV.

The difference between the two NPVs should, in my opinion, be taken as the true value of the company's human resource asset.

In terms of an equation:

$\mathrm{HRA}=\mathrm{NPV} 1$ less NPV2

Where NPV1 is the net present value expected to be generated by the company's existing staff and NPV2 is the net present value expected to be generated if the company had only average quality staff.

\section{Example}

ABC Ltd believes that its human resource is far superior to that of its competitors. Its management prepares the following discounted cash-flow projections, for two scenarios. Case X represents the net present value expected to be achieved through the efforts of its current human resource while Case Y represents the net present value to be achieved by the company with similar assets but inferior human resource. Here the word inferior is relative to the quality of company's existing human resource but intended to represent the average of the industry in which ABC Ltd operates.

\begin{tabular}{ccc}
\hline Year & $\begin{array}{c}\text { NPV under Case X } \\
\text { (existing HR, at firm's } \\
\text { WACC) } \\
\text { \$ millions }\end{array}$ & $\begin{array}{c}\text { NPV under Case Y } \\
\text { (Average HR, at } \\
\text { industry's average } \\
\text { WACC) } \\
\text { \$ millions }\end{array}$ \\
\hline 1 & 245 & 218 \\
2 & 285 & 254 \\
3 & 322 & 287
\end{tabular}

\begin{tabular}{ccc}
4 & 354 & 315 \\
5 & 391 & 348 \\
6 & 424 & 377 \\
7 & 462 & 411 \\
8 & 505 & 449 \\
9 & 551 & 490 \\
10 & 612 & 545 \\
Total & 4,151 & 3,694 \\
\hline
\end{tabular}

Case X represents NPV1 while Case Y represents NPV2. Their difference $\$ 467$ million is equal to the human resource asset commanded by the company.

\section{Possible criticism on HRA = NPV1 less NPV2}

It is possible to criticize the above equation on the grounds of subjectivity. NPV1 is probably not a disputed issue as all companies do compute their own (or their desired acquisitions') net present value from time to time. The main issue is "how accurately can a company compute the Case Y figure: NPV2?" My answer to this question is that a company should be equally realistic in computing both the NPVs. The task can be assigned to a board committee, or a team comprising of internal and external experts in order to minimize the impact of subjectivity and to ensure coverage of all pertinent factors that influence company's future cash flows.

A related criticism on using the NPV approach refers to the diversity of different factors that potentially affect the computation of NPV. This is essentially true. A number of factors other than human resource element may affect the computation of NPV of a firm. But this does not impair the validity of HRA/HRR Preposition. There should be no difference in factors to be kept in mind when computing NPV1 and NPV2 other than the difference in quality of human resource. Identical market, operational and economic conditions should be assumed in all respects. Hence, the resultant difference between NPV1 and NPV2 should be assignable purely to the quality of human resource asset commanded by the firm.

Another possible criticism could be that this equation ignores the actual expenditure incurred on training and developing its human resource asset. While I intend to cover this aspect in a later paragraph of this paper, I believe that the "value" of a non-tangible asset should be independent of the "cost" incurred to obtain it. The value of human resource asset (or for that matter any asset) lies in its potential to generate future cashflows. It is the quantum of future cashflows, not the expenditure incurred previously, that represents an asset to the company. The two should be kept apart - except 
for treatment of extra-ordinary expenditure on special training and development whose treatment is also dealt with in a later paragraph. An example may be cited here of revaluation of fixed assets, primarily land and buildings. Many companies find it helpful to show their land and buildings at market value (placing the gain on revaluation in a capital reserve account) which is quite different from the "cost" of these assets. There is no theoretical or legal logic that declares such a treatment unethical or improper.

\section{NPV Computation Horizon}

For the sake of clarity, I may add here that NPV may be computed over a reasonable period, appropriate to the life cycle and nature of industry in which a company operates. For many companies a NPV based on cashflows for the next 10 years may be quite satisfactory; for certain industries (like hotels, cements plants, etc.) cash flow projections may be made for longer periods. And for certain companies that are engaged in rapidly changing technologies; a shorter period like five years may be more appropriate for forecasting cashflows and computing NPV.

\section{How to show the value human resource asset in the balance sheet?}

Once the value of human resource asset (HRA) has been determined, I propose that an accounting entry be made in the books of the company as follows:

\section{Debit Human Resource Asset (HRA) Credit Human Resource Reserve (HRR)}

The HRA should be shown in the balance sheet along with the other non-tangible assets while the HRR should be shown as part of the company's equity as a non-distributable reserve, a sort of capital reserve that cannot be paid off to shareholders as (cash or scrip) dividends. This treatment is quite similar to accounting entries made on revaluation of fixed assets - and does not breach any existing accounting standard; nor does it subject the company to any unfair tax disadvantage. However, a suitable note to this effect should be given within the financial statements where accounting policies are disclosed. This note should give the basis and manner of computation of HRA and steps taken to ensure its objectivity.

\section{Human Resource Reserve Aspect}

Treating HRR as a part of equity simply reaffirms the right of equity holders to the residual value of company's assets. The recommendation to classify it as a non-distributable reserve is to ensure this reserve will be available to equity holders only at the time of company's liquidation and to prevent unwarranted cash outflows during the life of the company. Just as it would be inappropriate to create a goodwill asset in the books and issue bonus shares in lieu thereof to the shareholders, I hold the view that Human Resource Reserve should remain a non-distributable part of a company's equity. Nonetheless, presence of this reserve will enhance the book value of each share of the company with potential impact on its market value in due course.

\section{Annual enhancement in firm's HRA}

Once HRA and HRR accounts have been created, the company should also look at the reasons that give rise to this asset. Clearly, one of the causes of this asset is the expenditure that is incurred on hiring, training and development of employees. I propose that this training and development expense should be divided into two distinct (but not necessarily equal) segments: the normal staff training and development that an average company incurs any way and the special higher expense that a company incurs to ensure the continued higher quality of their employees' performance. Clearly, it is the second T\&D expense that gives the company a competitive edge. Measuring such a special expense each year should not offer any problems. One simple way of measuring it would be to deduct the average T\&D expense per employee incurred by companies in the pertinent industry from the company's own T\&D expense per employee - and multiplying the resultant figure with the number of company's total employees.

$$
\mathrm{Z}=\mathrm{A}-(\mathrm{B} \times \text { No of employees })
$$

Where $\mathrm{Z}$ is Special T\&D expense incurred by the company in a particular year

A is total Training and Development expense incurred in the year by the company

and $B$ is average T\&D expense per employee of the industry.

\section{Example}

ABC Ltd, a manufacturer of domestic use chemicals, has a total of 7,200 employees. During the past year it spent a total of $\$ 9.2$ million on training and development of its human resource. Companies in similar industry spend on average $\$ 900$ per employee per year on training and development. The "capitalizable" portion of company's training and development expense would be computed as follows: 
$\mathrm{Z}=\mathrm{A}-(\mathrm{B} \times \mathrm{N}$ No of employees $)$

$Z=\$ 9.2$ million $-(7,200 \times 900)=\$ 2.72$ million

Once measured, it is proposed that this expense should be treated as follows:

The normal accounting entry should be:

Debit usual training and development expense account

Credit cash

This entry should be made in respect of the total expenditure (\$9.2 million) made on human resource training and development, i.e. inclusive of normal and special expenses.

In addition, a further entry should be made

\section{Debit HRA}

Credit HRR

This entry should be made only for the amount of special, extra-ordinary higher expenditure incurred on HR training and development $(\$ 2.72$ million, computed as $\mathrm{Z}$ above) that in the opinion of the company's management gives it an extra edge over the competition.

In this way, the company will not lose any tax advantage on the entire expense incurred on training and developing its manpower, but at the same time, the value of HRA and HRR, will be shown at an enhanced, more appropriate level in the balance sheet.

At least theoretically, it is possible that in any particular year, $\mathrm{Z}$ score may be negative for a firm. In such a case the entry should be:

\section{Debit HRR \\ Credit HRA}

with the amount of $Z$ (excess of average T\&D expense per employee incurred by the industry over T\&D expense per employee $\mathrm{x}$ number of employees of the firm.

\section{Periodic review of HRA and HRR}

Nothing remains constant in the life of a company, however stable it may appear to be. It is therefore proposed that every company that adopts my proposed HRA/HRR method, should carry out re-assessment of the value of its human resource asset every three to five years, using the same formula, i.e. preparing two sets of projected cash flows.

If the new computation shows a higher positive difference between the two NPV figures, it means the value of company's human resource assets has improved. The quantum of improvement would be computed as follows:

The new human resource asset value (as computed now)

Minus HRA (and HRR) as currently shown in the balance sheet.

An accounting entry can then be passed enhancing both the HRA and HRR balances.

\section{Debit HRA}

Credit HRR (with the amount of difference as computed above)

However, if the new computation shows that the current value of company's human resource asset is less than the one carried in the balance sheet (e.g. due to excessive capitalization of special T\&D expenses), the difference should be written off by

debiting HRA and

crediting HRR (with the amount of difference computed above).

This will have no tax implications and no impact on company's income statement and dividends.

\section{An Important Proviso}

Entries in the HRA account and the HRR account have been proposed to come from two sources. Firstly, these can come through computation of difference in NPV1 and NPV2, and secondly from capitalizing the extra-ordinary expenditure on human resource training and development. It is proposed that at no time should the balance on these two accounts be larger than the amount computed as difference between NPV1 and NPV2.

In this regard, the following steps are proposed:

1. When the company decides to bring Human Resource Assets into books for the first time, it should simply compute the difference between NPV1 and NPV2 and bring it to books as outlined above. In that particular year, no entry should be made in respect of extra-ordinary expenditure on human resource training and development. This is so because the impact of this extra-ordinary expenditure is already reflected in the difference between the two net present values. 
2. In each subsequent year, entries may be made in respect of extra-ordinary expenditure on HR training and development as explained earlier. This will have the effect of altering the balances on HRA and HRR accounts created in the first year. The justification for this entry is that such an extra-ordinary expenditure has improved the value of the HRA since it was last determined.

3. Periodically, say every three to five years, the value of HRA should be re-assessed by computing the difference between NPV1 and NPV2. The balances on HRA and HRR accounts should be brought in line with the newly computed value.

4. At least theoretically a company may re-compute the value of its HRA by computing the difference between NPV1 and NPV2 every year. In such a case, there would be no need to, or justification for, making any entries in HRA / HRR accounts in respect of extra-ordinary expenditure on human resource training and development.

\section{Advantages of HRA/HRR method}

I sincerely believe the proposed method for valuation of human resource capital and bringing it into the balance sheet (and therefore in formal financial reporting) merits serious considerations on the following grounds:

a. It enables the company to show its most valuable asset in its balance sheet.

b. It brings the book value of a company's equity closer to its market value.

c. It is liable to give the most appropriate value of company's real HR asset.

d. It is easy to compute and explain to stakeholders.

e. It has no tax implications at any stage.

f. It takes into account the "unusual, special and extra-ordinary expenditure on HR training and development, without reducing company's tax shield.

g. It asks for, or at least allows, periodic revision of the value of HR asset.

h. The proposed accounting treatment does not breach any existing accounting standard, nor does it impair or improve company's reported profits and dividends.

\section{REFERENCES}

Bullen, M. L. (2007). Human resource accounting: A useful tool for measurement and management in organizations. Leadership and Organizational Management Journal, 5, 85-103.

Flamholtz, E. (1973). Human resources accounting:
Measuring positional replacement costs. Human Resource Management, 12(1), 8-16.

Flamholtz, E. G , Kannan-Narasimhan, R., \& Bullen, M.L.(2004). "Human Resource Accounting today: Contributions, controversies and conclusions". Journal of Human Resource Costing \& Accounting, 8(2), 23-37.

Flamholtz, E. G. (1979). TOWARD A PSYCHOTECHNICAL SYSTEMS PARADIGM OF ORGANIZATIONAL MEASUREMENT. Decision Sciences, 10(1), 71-84.

Flamholtz, E.G. (1999). "Human Resource Accounting: Advances, Concepts, Methods and Applications". Boston, MA: Kluwer Academic Publishers.

Flamholtz, E.G., Bullen, M.L., \& Hua, W. (2002). "Human Resource Accounting: A historical perspective and future implications". Management Decision, 40(10), 947-54.

Flamholtz, E.G., Bullen, M.L., \& Hua, W. (2003). "Measuring the ROI of management development: An application of the stochastic rewards valuation model". Journal of Human Resource Costing and Accounting, 7(1-2), 21-40.

Horngren, C.T. (1972). "Cost Accounting. A Managerial Emphasis". Prentice Hall Inc, Englewood Cliffs

Johanson, U. \& Mabon, H. (1998). "The personnel economics institute after ten years: What has been achieved and where we are we going?" Journal of Human Resource Costing and Accounting, 3(2), 65-76

Likert, R.M. (1961). "New Patterns of Management". New York: McGraw Hill Book Company.

Moore, R. (2007). "Measuring how 'human capital' appreciates in value over time". Plant Engineering, 61(4), 1-29.

Morrow, S. (1996). Football players as human assets. Measurement as the critical factor in asset recognition: A case study investigation. Journal of Human Resource Costing \& Accounting, 1(1), 7597.

Morrow, S. (1997). Accounting for football players. Financial and accounting implications of royal club liégois and others $\mathrm{V}$ Bosnian'for football in the United Kingdom. Journal of Human Resource Costing \& Accounting, 2(1), 55-71.

Olsson,B.(2001).Annualreportingpractices:information about human resources in corporate annual reports in major Swedish companies. Journal of Human Resource Costing \& Accounting, 6(1), 39-52.

Sackmann, S.A., Flamholtz, E. \& Bullen, M.L., (1989). "Human Resource Accounting: a state-of-the-art review". Journal of Accounting Literature, 8, 235264.

Sullivan, P.H. (2000), "Value-driven Intellectual 
Capital", Wiley \& Sons Publishing

Journal, 14(2), 75-90.

Toulson, P.K. \& Dewe, P.(2004). "HR Accounting as a Wagner, C.G. (2007). "Valuing a company's innovators".

Measurement Tool”. Human Resource Management

The Futurist, 41(5), 7 